\title{
Recenzje
}

DOI 10.14746/ssp.2019.3.11

\section{Wybrane wspótczesne nurty polskiej myśli politycznej, red. J. Kornaś, R. Lisiakiewicz, Wydawnictwo Adam Mar- szałek, Toruń 2016, ss. 328.}

Zamierzeniem Autorów było przedstawienie wybranych nurtów ideologicznych, które porządkują polskie partie polityczne według kryterium ideologicznego i programowego ${ }^{1}$. Warto docenić tę próbę, ze względu na różnorodność i złożoność polskich partii politycznych. Już we wprowadzeniu redaktorzy publikacji słusznie wskazali na eklektyzm oraz dynamikę przemian ideowych, obserwowaną w założeniach programowych polskich partii politycznych. Wśród przyczyn tego stanu rzeczy wyróżnili: niedojrzałość polskiego systemu partyjnego, uwarunkowania historyczne i kulturowe oraz specyfikę państw Europy ŚrodkowoWschodniej.

Książka składa się z pięciu rozdziałów, które odpowiadają zaprezentowanym przez Autorów nurtom polskiej myśli politycznej. Autorzy poszczególnych rozdziałów skupili się na aktywności politycznej oraz tożsamości polskich partii politycznych.

Jerzy Kornaś przeanalizował nurt lewicowy, koncentrując się na głównych partiach: Socjaldemokracji Rzeczypospolitej Polskiej i Sojuszu Lewicy Demokratycznej. W rozdziale przedstawiono ewolucję polityczno-organizacyjną tych ugrupowań: samodzielne funkcjonowanie SdRP, następnie w koalicji SLD, a w konsekwencji przekształcenie koalicji SLD w partię polityczną.

Autor słusznie zauważył nieadekwatność zawartych w programach SdRP i SLD deklarowanych założeń dotyczących niwelowania negatywnych skutków transformacji gospodarczej. Potwierdzają to także inni badacze, analizujący rodzinę partii lewicowych $\mathrm{w}$ Polsce². SLD proponowało złagodzenie niekorzyst-

${ }_{1}$ M. Żmigrodzki, Kryterium ideologiczne i programowe, w: Teoria partii politycznych, red. M. Chmaj, W. Sokół, M. Żmigrodzki, Lublin 1999, s. 34-41.

2 T. Godlewski, Lewica $w$ systemie partyjnym III RP, w: Partie i system partyjny III RP, red. K. Kowalczyk, Toruń 2011, s. 114-115. 
nych efektów zmian ekonomicznych poprzez interwencjonizm państwa oraz równoprawność różnych form własności. W praktyce działania interwencjonistyczne były ograniczone, co podkreśla Autor, ze względu na niski wzrost gospodarczy, wysoki deficyt budżetowy oraz wysokie bezrobocie.

J. Kornaś, odwołując się do Lecha Mażewskiego, stwierdził, że wysokie poparcie społeczeństwa w 2001 roku i następnie okres sprawowania władzy niekorzystnie wpłynęły na SLD. W partii uznano, że przeciwnik polityczny jest słaby, co z jednej strony wpłynęło na osłabienie jej spójności, z drugiej strony wywołało kryzys sprawowania władzy. Autor właściwie ocenił przyczyny marginalizacji SLD, choć może zbyt mało miejsca poświęcił aferom, które spowodowały spadek notowań formacji lewicowej. J. Kornaś wskazał jedynie tzw. aferę Rywina, pomijając inne, np. aferę starachowicką. Odcięcie się od założeń i dziedzictwa programowego J. Kornaś uznał jako jedną z głównych przyczyn porażki kandydatki na SLD na urząd prezydenta Magdaleny Ogórek.

Za wartościowe należy uznać przedstawienie toczącej się w kręgach intelektualnych SLD dyskusji dotyczącej przyszłości polskiej lewicy. Autor odwołując się do Jerzego Wiatra określił sposób prowadzenia polityki przez SLD po 2005 roku jako „działalność reaktywną”, czyli sprowadzającą się wyłącznie do reakcji na aktywność obozu rządzącego. Godny podkreślenia jest wykorzystany przez Autora bogaty materiał źródłowy.

Kolejnym nurtem analizowanym w książce jest nurt liberalno-konserwatywny. Autorem rozdziału jest Łukasz Danel. Autor w nurcie liberalno-konserwatywnym umieścił następujące partie: Unię Polityki Realnej, Kongres LiberalnoDemokratyczny, Unię Demokratyczną, Unię Wolności, Partię Demokratyczną, Platformę Obywatelską, Partię Demokratyczną - Demokraci.pl oraz Nowoczesną. Wydaje się, że ze względu na analizowane formacje polityczne bardziej precyzyjne byłoby określenie tego nurtu jako liberalny.

Wątpliwości może budzić zaliczenie do nurtu konserwatywno-liberalnego UD oraz KLD. O ile można wytłumaczyć zaliczenie tu UD, ze względu na funkcjonujące $\mathrm{w}$ ramach tej partii skrzydło konserwatywne, to zupełnie nie można zgodzić się z przyporządkowaniem KLD do nurtu konserwatywno-liberalnego. Ugrupowanie to, szczególnie w początkowym okresie działalności reprezentowało liberalizm integralny, zarówno w sferze ekonomicznej, jak i kulturowej. Także UW badacze przyporządkowują do rodziny partii liberalnych ${ }^{3}$.

Do nurtu konserwatywnego nie można zaliczyć partii Demokraci.pl, którą współtworzyli także politycy związani z nurtem lewicowym. Część działaczy tej formacji startowała w wyborach $\mathrm{z}$ ramienia komitetów lewicowych (SLD Lewica Razem, Koalicyjny Komitet Wyborczy Porozumienie dla Przyszłości - Centro-

3 Por. M. Wincławska, Unia Wolności. Partia Polityczna $w$ okresie transformacji, Warszawa 2010, s. 141; W. Sokó1, Partie polityczne i system partyjny w Polsce w latach 1991-2001, w: Współczesne partie i systemy partyjne. Zagadnienia teorii i praktyki politycznej, Lublin 2003, s. 210. 
lewica). W 2012 roku Demokraci.pl współtworzyli lewicowy projekt polityczny pod nazwą Europa Plus, w skład którego weszły SDPL, Unia Pracy oraz Ruch Palikota. Autor notabene informacje te w artykule podaje. Dlatego należałoby przyporządkować tę formację do nurtu lewicowo-liberalnego.

Za właściwe należy uznać przyporządkowanie PO do nurtu konserwatywnoliberalnego. Można było jednak wyraźniej wskazać uzasadnienie tego przyporządkowania, które widoczne jest $\mathrm{w}$ genezie oraz elitach przywódczych tej partii. PO powstała jako połączenie środowisk liberalnych (politycy UW, tworzący wcześniej KLD) z konserwatywnymi (część Stronnictwa Konserwatywno-Ludowego, część członków RS AWS).

Na pozytywną ocenę zasługuje zauważenie przez Autora ewolucji tożsamościowej PO i odejście od konserwatyzmu w wymiarze tożsamościowym. Wynikało to ze zmian w elicie przywódczej partii oraz chęci poszerzenia elektoratu o środowiska lewicowe. Autor wskazuje, że pomimo deklarowanego przywiązania do wartości chrześcijańskich, w okresie sprawowania urzędu premiera przez Ewę Kopacz, PO przeforsowała dwie kontrowersyjne ustawy. Pierwsza dotyczyła prawnego uregulowania kwestii in vitro, druga ratyfikacji konwencji o zapobieganiu i zwalczaniu przemocy wobec kobiet.

Stosunkowo dużo uwagi Autor poświęcił kwestiom międzynarodowym. Analiza dokumentów programowych pozwoliła na ukazanie najważniejszych założeń programowych w tym zakresie, PO można było określić jako formację proeuropejską, postulującą zachowanie przyjaznych kontaktów z wszystkimi sąsiadami. Autor prawidłowo zauważył kontynuację polityki PO w stosunku do UD i UW.

Kolejnym nurtem analizowanym w książce jest nurt określony jako: konserwatywny i narodowo-katolicki. Agnieszka Latosińska umieściła w nim następujące partie i ugrupowania polityczne: Prawo i Sprawiedliwość, Prawica Rzeczypospolitej, Polska Jest Najważniejsza oraz Kukiz'15. Wydaje się, że niesłusznie pominięta została w opracowaniu Liga Polskich Rodzin. Tym bardziej, że w jednym z kolejnych rozdziałów analizowana jest działalność Samoobrony RP, z którą LPR współtworzyła koalicję rządzącą w latach 2006-2007. Analiza działalności LPR pozwoliłaby na wyjaśnienie zmiany tożsamościowej PiS z partii konserwatywnej w kierunku partii narodowo-katolickiej, która dokonała się m.in. w wyniku wchłonięcia elektoratu LPR przez PiS. Autorzy opracowania we Wstępie określili cezurę czasową jako przełom lat 80. i 90. XX wieku. Jeśli przyjęto takie ramy, to przy analizie ruchu narodowo-katolickiego powinny zostać omówione takie partie, jak: Stronnictwo Narodowe, czy Porozumienie Polskie.

Autorka ukazała założenia programowe PiS, wskazując $w$ ich podstawach na wartości chrześcijańskie, ideę silnego państwa i antykomunizm w wymiarze tożsamościowym oraz etatyzm w sferze ekonomicznej. W dorobku programowym PiS istotne były dwa projekty konstytucyjne z 2005 i 2010 roku, z których jeden w opracowaniu przeanalizowano. Poprzez analizę dokumentów partyjnych przedstawiono także podstawy programowe ugrupowań, które wyłoniły się z PiS w wyniku sporów ideologicznych oraz personalnych. 
Nurt ludowy przedstawiła Karolina Kotulewicz. Autorka skupiła się na aktywności oraz tożsamości Polskiego Stronnictwa Ludowego oraz Partii Ludowo-Demokratycznej. W opracowaniu zarysowano charakter przemian organizacyjnych PSL, w tym okoliczności przeobrażenia z partii autoryzującej aparat władzy Polskiej Rzeczypospolitej Ludowej w demokratyczną partię o charakterze agrarnym. Stało się to w wyniku umiejętnych działań polityków Zjednoczonego Stronnictwa Ludowego, którzy poprzez alians z opozycyjnymi działaczami „Solidarności” Rolników Indywidualnych uzyskali status demokratycznej partii chłopskiej. Autorka przedstawiła także późniejsze spory wewnątrz partii, dotyczące jej tożsamości. W opracowaniu wskazano także na postrzeganie tej partii jako formacji uzależniającej swoje stanowisko od ewentualnych korzyści i układu politycznego. To, zdaniem Autorki, przyczyniło się w 2001 roku do odpływu elektoratu w kierunku antyestablishmentowej Samoobrony RP. W kontekście toczącej się dyskusji dotyczącej przyczyn bardzo dobrego wyniku w wyborach samorządowych w 2014 roku, za interesujące, (ale wymagające potwierdzenia) można uznać stwierdzenie Autorki, że zostało to osiągnięte dzięki deklarowaniu przez PSL przywiązania do wartości rodzinnych i religijnych. Poprzez pryzmat działalności Partii Ludowo-Demokratycznej w opracowaniu ukazano także niemożliwość przełamania monopolu PSL w nurcie ludowym.

$\mathrm{Na}$ trudności z przyporządkowaniem Samoobrony RP do określonego nurtu ideologicznego wskazywało już wcześniej wielu badaczy. Pojawiały się m.in. koncepcje określenia tej formacji jako partii niestandardowej lub populistycznej. Dlatego też umieszczenie tej formacji przez Rafała Lisiakiewicza w nurcie nazwanym jako ludowo-populistyczny wydaje się słuszne. Autor celnie wypunktował przyczyny nieadekwatności głoszonych haseł do bieżącej aktywności politycznej. Samoobrona głosiła hasła antyelitystyczne, uwypuklając konieczność rozliczenia osób sprawujących władzę. Jednocześnie uwikłała się w mechanizmy rządzenia, co spowodowało utratę statusu partii relewantnej. Na uwagę zasługują także wnioski R. Lisiakiewicza dotyczące poglądów Samoobrony na temat akcesji Polski do Unii Europejskiej. Kiedy okazało się, że warunki wejścia Polski do UE nie są tak niekorzystne, jak przedstawiała je Samoobrona, poparcie dla tej partii spadło. Warte podkreślenia jest ukazanie formacji stanowiących kontynuację Partii Samoobrona: Partii Regionów oraz Partii Zmiana.

Analiza założeń ideologicznych polskich partii politycznych, w odniesieniu do aktywności politycznej jest zadaniem trudnym. W okresie transformacji ustrojowej zauważalna była duża dynamika w tym zakresie. Partie i ugrupowania polityczne ulegały przeobrażeniom w wymiarze tożsamościowym. Formacje polityczne bardzo często $\mathrm{w}$ ofercie programowej umieszczały założenia, będące eklektycznymi zestawieniami, czerpiącymi z różnych nurtów ideologicznych. W wielu przypadkach ich aktywność polityczna nie była rzeczywistym odzwierciedleniem założeń ideowych. Tym bardziej należy docenić inicjatywę badaczy, którzy dokonali analizy polskich partii politycznych, skupiając się na podstawach ideologicznych. Być może z uwagi na powyższe 
zastrzeżenia nie ustrzegli się pewnych błędów. Nie pomniejszają one jednak znaczenia tego opracowania.

Rekapitulując, należy podkreślić wartość recenzowanej publikacji ze względu na podejmowaną tematykę. Publikacja nie jest kompletnym kompendium przedstawiającym wszystkie nurty polskiej myśli politycznej, ale Autorzy zastrzegli to już w tytule publikacji. Należy traktować przedmiotową książkę jako istotną kolejną propozycję $\mathrm{w}$ dyskursie dotyczącym typologizacji polskich partii politycznych.

Tomasz BOJAROWICZ

Uniwersytet Warmińsko-Mazurski w Olsztynie 